\title{
Analisis dan Simulasi Networked Control Systems dalam Platform Robosoccer
}

\author{
Asep Najmurrokhman, Kusnandar, Sunubroto \\ Jurusan Teknik Elektro, Universitas Jenderal Achmad Yani \\ Jl. Terusan Jend. Sudirman PO Box 148 Cimahi 40533 \\ Email: asepnajmu@yahoo.com; koes_kusnandar@yahoo.com; sunubroto@gmail.com
}

\begin{abstract}
Abstrak - Robot sepakbola adalah kumpulan robot humanoid yang bekerja sama menghasilkan gol ke gawang lawan. Menurut FIRA (federation of international robosoccer association) sebagai organisasi yang mengembangkan robot sepakbola, penelitian terkait dengan robot sepakbola mencakup penelitian tentang koordinasi antar bagian dalam satu tim yang masing-masing anggotanya disebut agen, sehingga tim robot sepakbola disebut multi agent. Setiap agen memiliki dinamika dan karakteristik spesifik tetapi secara keseluruhan tim tersebut harus berkoordinasi mencapai tujuan yang diinginkan. Koordinasi antar agen dilakukan dengan protokol komunikasi tertentu dan melalui skema pengendali terdistribusi. Dalam konteks NCS, sistem robot sepakbola adalah sistem NCS yang pengendalinya terdistribusi dalam ruang dan saling berkoordinasi dengan memanfaatkan jaringan komunikasi. Makalah ini menguraikan tentang kerangka kerja NCS dalam platform robot sepakbola. Berbagai hal terkait dengan parameter jaringan komunikasi dan pengaruhnya dalam sistem akan dibahas dan secara spesifik diterapkan dalam platform robot sepakbola.
\end{abstract}

Kata Kunci: networked control systems, robot sepakbola

\section{PENDAHULUAN}

Lebih dari satu dekade, perkembangan teknologi komputasi dan komunikasi maju dengan pesat. Sebagai akibat dari perkembangan tersebut, implementasi sistem kendali akhir-akhir ini diarahkan menuju sistem kendali melalui jaringan komunikasi. Sistem kendali yang melibatkan jaringan komunikasi sebagai bagian dari lingkar kendali disebut sebagai networked control systems (NCS) [Hespanha, 2007]. Penggunaan jaringan komunikasi menawarkan keuntungan yang cukup signifikan dalam hal keandalan, penggunaan sumber daya, pemeliharaan, diagnosa sistem apabila terjadi kesalahan, dan sebagainya [Zhang, 2001]. Aplikasi NCS dapat ditemukan dalam kendaraaan yang menerapkan kendali otomatis, robotika, pesawat udara nirawak (unmanned aerial vehicle), jaringan sensor nirkabel, dan sebagainya [Varsakelis, 2005]. Disamping keuntungan yang ditawarkan, ada beberapa parameter yang muncul dalam jaringan komunikasi seperti waktu tunda transmisi dan kemungkinan hilangnya data saat transmisi yang bisa menyebabkan penurunan kinerja sistem dan bahkan bisa menyebabkan ketidakstabilan [Zhang, 2001]. Heemels, dkk. (2010) menyimpulkan beberapa parameter jaringan yang harus dipertimbangkan meliputi waktu tunda transmisi data yang bervariasi, adanya kemungkinan data hilang (yang disebut packet dropout) di tengah jalan akibat ketidakhandalan jaringan, adanya error kuantisasi disebabkan keterbatasan panjang kata (finite word length), interval pencacahan yang berubah-ubah secara acak, dan penggunaan bersama jaringan oleh beberapa komponen (multi nodes). Secara skematik, sebuah NCS diberikan dalam gambar 1.

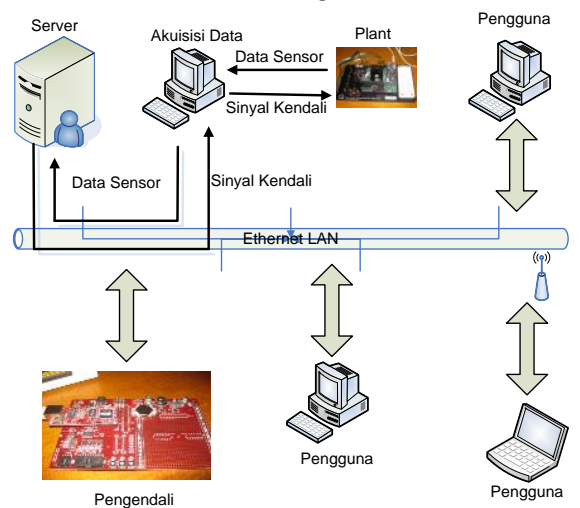

Gambar 1. Skema NCS [Najmurrokhman, 2010]

Dalam gambar tersebut, sebuah objek (yang disebut plant) akan dikendalikan oleh pengendali melalui jaringan komunikasi yang digunakan bersama-sama dengan pengguna lainnya. Keberadaan pengguna lain dalam kanal komunikasi memungkinkan volume data yang ditransmisikan sangat padat, sehingga terjadi waktu tunda transmisi data dari pengendali ke plant atau sebaliknya. Kondisi lain yang mungkin terjadi adalah hilangnya paket data (packet dropout) karena ketidakhandalan jaringan atau akibat penumpukan data yang melebihi kapasitasnya (buffer overflow). Dengan demikian, perancangan dan implementasi NCS harus mempertimbangkan parameter jaringan tersebut. Berbagai metode telah dikembangkan oleh para peneliti dalam hal pemodelan, analisis stabilitas, 
dan perancangan pengendali untuk NCS yang mempertimbangkan keberadaan parameter jaringan komunikasi. Karena penelitian dalam bidang NCS masih tergolong baru, hasil-hasil yang dilaporkan dalam literatur masih mempertimbangkan beberapa parameter jaringan di atas, sementara parameter jaringan lainnya diabaikan. Rasool (2011), Shi (2011), Shi (2009), Gao (2008), dan Lam (2007) melibatkan efek waktu tunda transmisi, kehilangan paket data, dan kuantisasi dalam kinerja NCS kemudian merancang pengendali yang mampu mengatasi parameter tersebut. Sementara itu, Wang (2011) dan Zhao (2011) menguraikan NCS dengan parameter packet dropout dan waktu tunda transmisi. Peneliti lainnya melibatkan faktor kehilangan data dalam pemodelan NCS, kemudian menurunkan karakterisasi eksak dalam sintesis pengendali [Ma (2010), Aberkane (2008), Hirche (2008), Ishii (2008)]. Makalah lain membahas tentang efek kuantisasi dalam NCS kemudian mengembangkan sebuah pengendali yang mampu menangani efek tersebut [Nesic \& Liberzon, (2009)].

Di lain pihak, robot sepakbola menjadi tren penelitian dalam bidang kendali yang sedang berkembang cukup pesat. Hal tersebut dimotivasi oleh penyelenggaraan kompetisi robot sepakbola di ajang internasional dalam bentuk Robocup. Tahun 2012 adalah penyelenggaraan Robocup ke-16 yang bertempat di Mexico City, Mexico. Di Indonesia sendiri, kompetisi robot sepakbola dimulai tiga tahun terakhir dalam salah satu event di Kompetisi Robot Cerdas Indonesia (KRCI). Tujuan penyelenggaraan Robocup adalah mempromosikan penelitian terkait bidang robotika dan kecerdasan buatan (artificial intelligence). Salahsatu impian dari penggagas Robocup seperti dilansir dalam laman www.robocup.org adalah menghasilkan tim robot humanoid otonom pada tahun 2050 yang mampu melawan tim sepakbola pemenang Piala Dunia. Pengembangan robot sepakbola terkait dengan teknologi sensor, prosesor, dan komunikasi antar robot. Dalam sebuah tim robot sepakbola, beberapa robot bekerja sama saling memindahkan bola dan berkoordinasi menghasilkan gol di gawang lawan seperti digambarkan dalam gambar 2 .

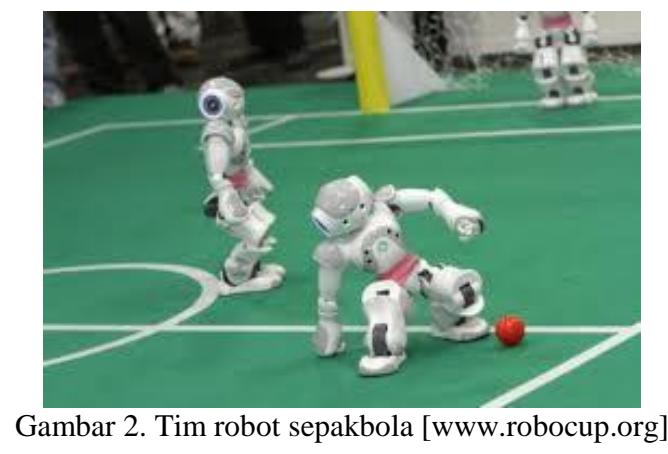

Dalam konteks NCS, tim robot sepakbola adalah robot-robot yang dihubungkan melalui jaringan 123 | ISBN 978-602-18241-1-5 komunikasi. Ada dua tipe jaringan komunikasi yang dikembangkan dalam penelitian terkait dengan robot sepakbola ini, yaitu melalui mekanisme client server dan otonom. Dalam mekanisme client server, operator akan memberikan instruksi kepada robot untuk bergerak ke arah bola. Operator tersebut mensimulasikan pelatih sepakbola yang memberikan arahan kepada pemain bola dalam memainkan peranannya di lapangan selama pertandingan berlangsung. Sementara itu, robot sepakbola otonom memberikan kepercayaan penuh kepada robot-robot humanoid yang berada di lapangan dalam bermain. Dalam konfigurasi tim sepakbola otonom, media komunikasinya umumnya berbentuk wireless. Oleh karena itu, tujuan penelitian robot sepakbola adalah merancang sistem robot humanoid yang dilengkapi dengan sensor yang memadai sehingga mampu berkomunikasi secara wireless dengan robot humanoid lain dan mampu menghasilkan gol ke gawang lawan.

Menurut FIRA (federation of international robosoccer association) sebagai organisasi yang mengembangkan robot sepakbola, penelitian terkait dengan robot sepakbola mencakup penelitian tentang koordinasi antar bagian dalam satu tim yang masingmasing anggotanya disebut agen, sehingga tim robot sepakbola disebut multi agent. Setiap agen memiliki dinamika dan karakteristik spesifik tetapi secara keseluruhan tim tersebut harus berkoordinasi mencapai tujuan yang diinginkan. Koordinasi antar agen dilakukan dengan protokol komunikasi tertentu dan melalui skema pengendali terdistribusi. Dalam konteks NCS, sistem robot sepakbola adalah sistem NCS yang pengendalinya terdistribusi dalam ruang dan saling berkoordinasi dengan memanfaatkan jaringan komunikasi. Dengan demikian, berdasarkan uraian sebelumnya, salahsatu keberhasilan dalam robot sepakbola adalah menangani parameter jaringan komunikasi yang muncul seperti waktu tunda transmisi dan kehilangan paket data selama pertukaran data antar robot. Beberapa penelitian terkini terkait dengan robot sepakbola diantaranya penggunaan komunikasi dengan menggunakan bahasa manusia [Schiffer, dkk. (2012), Argall, dkk. (2005)], pengembangan algoritma pengendali menggunakan jaringan syaraf tiruan [Jolly, dkk. (2007)], dan konstruksi protokol komunikasi untuk mendukung sistem robot sepakbola [Sanfeliu, dkk. (2008)].

\section{ROBOT HUMANOID}

Platform robot sepakbola dibangun oleh setiap robot humanoid yang dilengkapi dengan kemampuan pengenalan objek dan gerak yang fleksibel serta komunikasi antar robot. Salahsatu tipe robot humanoid yang telah dan sedang dikembangkan diperlihatkan dalam gambar 3. Komponen utama pendukung robot sepakbola adalah sensor, prosesor, motor dan drivernya, serta algoritma pengendali yang efektif 
mendukung keberhasilan pencapaian tujuan pengendaliannya.

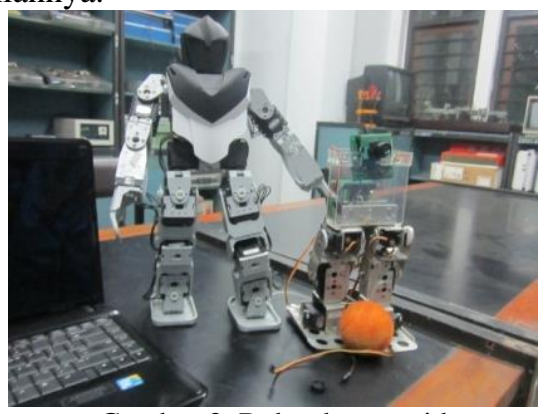

Gambar 3. Robot humanoid

Sensor utama yang harus dimiliki oleh robot sepakbola adalah gyroscope dan sensor kamera. Gyroscope adalah suatu alat berupa sensor gyro untuk menentukan orientasi gerak dengan bertumpu pada roda atau cakram yang berotasi dengan cepat pada sumbu seperti diperlihatkan pada gambar 4 .

\section{MEMS Rate Gyroscope}

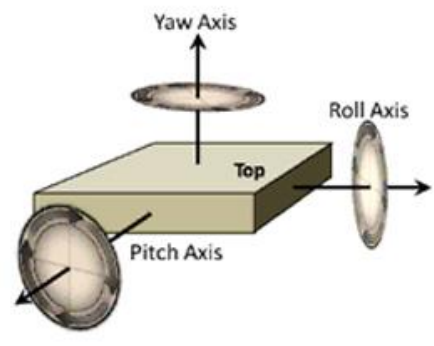

Gambar 4. Sensor gyroscope

Gyroscope memiliki output yang peka terhadap kecepatan sudut dari arah sumbu x yang nantinya akan menjadi sudut phi (roll), dari sumbu y nantinya menjadi sudut theta (pitch), dan sumbu $\mathrm{z}$ nantinya menjadi sudut psi (yaw). Penggunaan gyroscope pada robot humanoid adalah sebagai sensor keseimbangan yang dimana apabila robot jatuh dapat berdiri sendiri tanpa bantuan manusia. Sementara sensor kamera yang digunakan adalah CMUcam2 yang diperlihatkan dalam gambar 5 dan diagram bloknya pada gambar 6 . CMUcam2 terdiri dari SX52 mikrokontroler dengan antarmuka OV6620 atau OV7620 Omnivision CMOS camera dalam sebuah Chip. Modul komunikasi menggunakan RS-232 atau TTL serial port. Pergerakan dengan gambar yang berbeda 26 gambar perdetik. Jenis kamera ini memiliki resolusi maksimum 160 x 255 dengan kemampuan menangani servo sebanyak 5 buah dan kecepatan transmisi data (dalam satuan baudrates) sebesar 115200, 57600, 38400, 19200, 9600, 4800, 2400, dan 1200 . CMUcam2 digunakan sebagai sensor penglihatan pada robot humanoid. Semua warna yang ditangkap oleh camera diolah pada prosesor CMUcam dan dikodekan untuk dapat mengontrol robot, sehingga robot dapat menendang bola berwarna jingga. Selain itu robot juga dapat membedakan warna untuk memasukkan bola tersebut ke dalam gawang. Untuk menambah 124 | ISBN 978-602-18241-1-5 kemampuan robot sepakbola, selain dua sensor diatas ditambahkan pula sensor kompas dan sensor tekanan untuk mendeteksi orientasi robot dan pengukuran jarak.

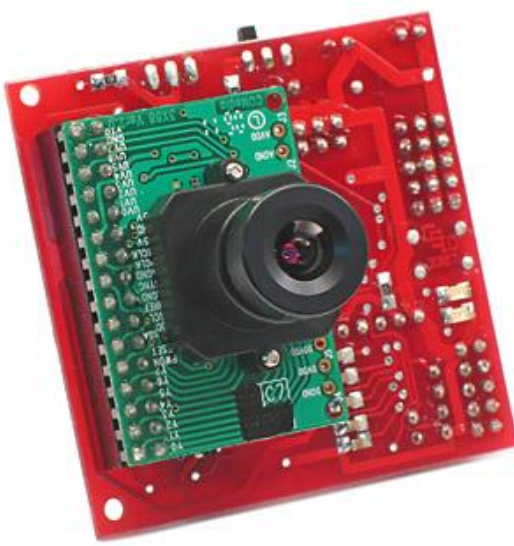

Gambar 5.CMUcam2 GUI

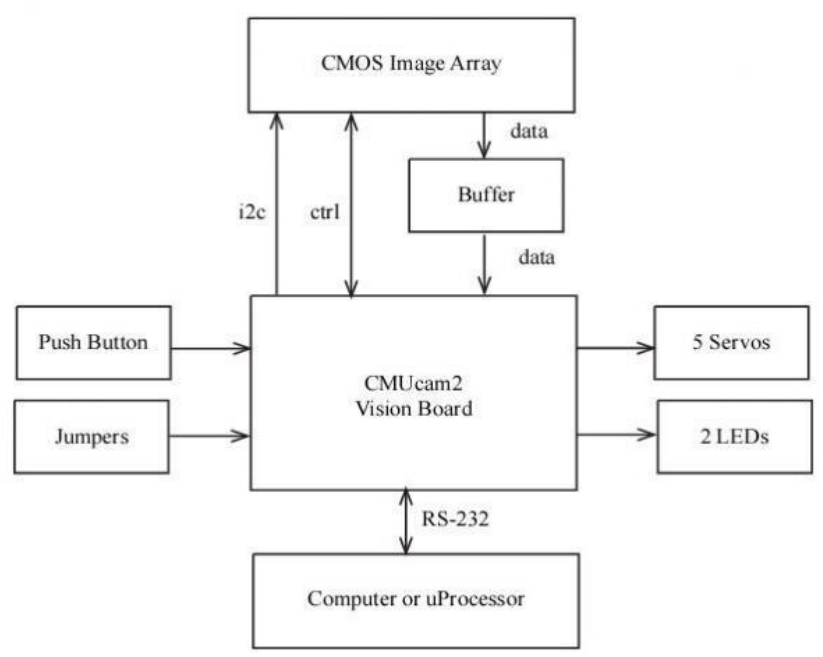

Gambar 6. Diagram blok CMUcam2 GUI

Secara konseptual, gerak robot menendang bola diperlihatkan pada gambar 7 dan 8. Gambar tersebut mengilustrasikan tendangan penalti yang akan dilakukan robot. Dalam hal ini, posisi bola didefinisikan sebagai pusat tujuan. Awalnya, robot mengenali posisi bola. Kemudian, robot itu sendiri memulai posisi dari arah A ke B dan robot bergerak menuju posisi yang berada di belakang posisi bola. Secara teoretis, posisi ini disebut dengan subgoal (posisi B), dan ini ditentukan dari arah berlawanan dari bola dan pusat tujuan dengan daerah pada offset tertentu. Namun, karena keterbatasan bidang pandang kamera dan arsitektur kamera tunggal, sulit untuk tepat menentukan posisi subgoal secara akurat. Oleh karena itu, robot hanya bergerak menuju ke subgoal 
kecil pada daerah offset sekitar 5-10 cm. Ketika robot bergerak di sekitar subgoal, robot mencoba untuk bergerak sendiri sehingga bola dan pusat tujuan berada di depan robot.

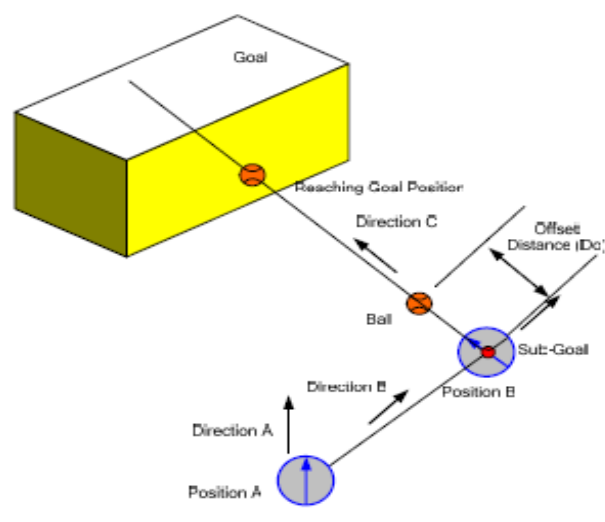

Gambar 7. Menendang dengan kondisi tanpa penjaga gawang.

Pada saat ini, robot ini sangat dekat dengan subgoal teoretis. Selanjutnya, robot bergeser kiri atau kanan sehingga bola berada di depan satu kaki. Akhirnya, robot bergerak sendiri untuk mencapai bola dan kemudian menendang bola ke gawang. Situasi lain adalah dirancang untuk kasus dengan penjaga gawang, seperti ditunjukkan pada Gambar 8. Kasus ini mirip dengan kasus sebelumnya, namun posisi bola tidak didefinisikan oleh pusat tujuan. Sebaliknya, kita mendefinisikan posisi mencapai tujuan dengan batas tujuan dan lokasi tujuan penjaga gawang. Praktis, posisi mencapai tujuan dipilih sebagai ruang yang lebih besar dari penjaga gawang dan setiap batas lokasi tujuan. Mirip dengan kejadian sebelumnya, robot bergerak ke posisi subgoal awal (posisi B). Ketika robot mencapai posisi subgoal awal, menentukan posisi yang lebih baik untuk mencapai tujuan yaitu subgoal. Kemudian, robot itu sendiri bergeser ke subgoal baru yang mungkin untuk menendang bola ke posisi tujuan mencapai.

Dalam satu tim robot sepakbola, pola pergerakan robot menjadi lebih kompleks. Selain harus mendeteksi pergerakan bola, setiap robot harus mengenali anggota tim dan juga lawannya. Komunikasi antar robot dalam satu tim bisa menggunakan sinyal suara atau deteksi warna. Dalam konteks NCS, setiap robot harus memiliki kemampuan mengenali teman satu tim dan lawannya serta memberikan informasi posisi relatif terhadap temannya agar bisa menyelesaikan tugasnya dihadapkan kepada kendala komunikasi yang mungkin muncul seperti adanya waktu tunda sinyal komunikasi atau adanya kemungkinan informasi dari salah satu robot tidak mencapai robot yang lain, dan sinyal gangguan dari luar. Berbeda halnya dengan implementasi NCS di industri atau aplikasi jaringan sensor yang bersifat statis, platform robot sepakbola menghasilkan konsep NCS untuk sistem yang dinamis. Dalam perkembangannya, konsep NCS untuk sistem dinamis seperti robot sepakbola atau koordinasi antar pesawat, sistem pengaturan lalu lintas secara otomatis, dan sebagainya mempertimbangkan dinamika dari setiap pergerakan bagian-bagian dalam sistem tersebut.

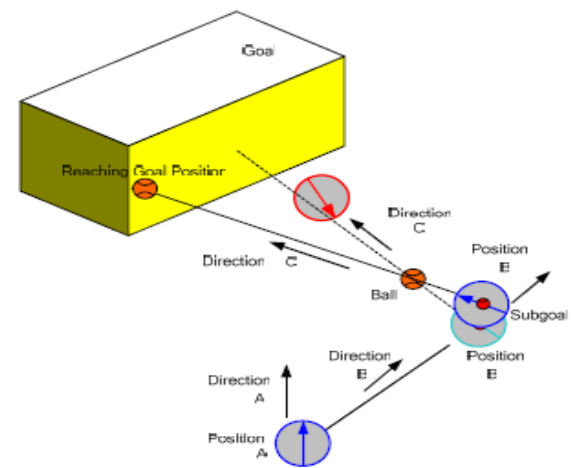

Gambar 8. Menendang dengan kondisi ada penjaga gawang

\section{SIMULASI ROBOT SEPAKBOLA}

Berkaitan dengan simulasi robot sepakbola, TrueTime Simulator yang dibangun oleh peneliti Lund University sejak tahun 1999 memungkinkan untuk mensimulasikan konsep NCS dalam robot sepakbola [Andersson, dkk. (2005)]. Dalam perangkat simulasi ini, semua pemain dimodelkan oleh blok yang tersedia dalam library-nya serta komunikasi antar pemain ditentukan melalui fasilitas yang ada dalam library yang lain. Setiap pemain robot sepakbola dalam simulator ini disebut mote. Dinamika setiap pemainnya ditentukan dan diasumsikan bergerak secara planar (datar). Bentuk diagram blok dari setiap pemain dalam robot sepakbola diperlihatkan dalam gambar 9 .

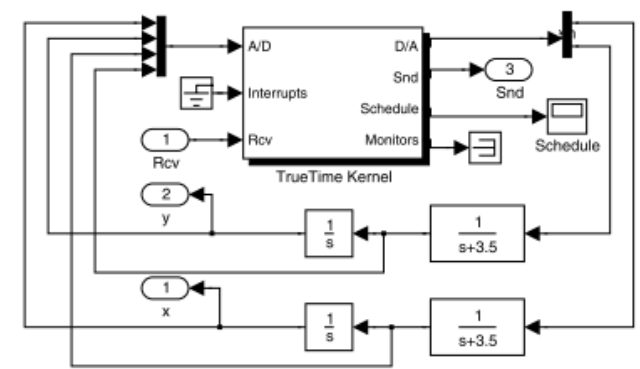

Gambar 9. Diagram blok untuk tiap pemain dalam robot sepakbola

Dalam gambar 9 diperlihatkan setiap mote bergerak dalam arah sumbu x dan sumbu y secara bebas. Selain itu, setiap mote memiliki dua buah output D/A yang menyatakan arus motor listrik yang digunakan. 
Dinamika antara arus dan posisi motor diberikan oleh fungsi transfer dalam blok tersebut. Dalam sistem ini, posisi dan kecepatan setiap robot diasumsikan dapat ditentukan secara langsung, sehingga memiliki empat buah input A/D untuk sinyal-sinyal tersebut. Komunikasi antara mote difasilitasi oleh port Snd dan Rcv. Salahsatu tampilan dari simulator yang menggambarkan proses memasukkan bola ke gawang diperlihatkan dalam gambar 10, 11, dan 12 .

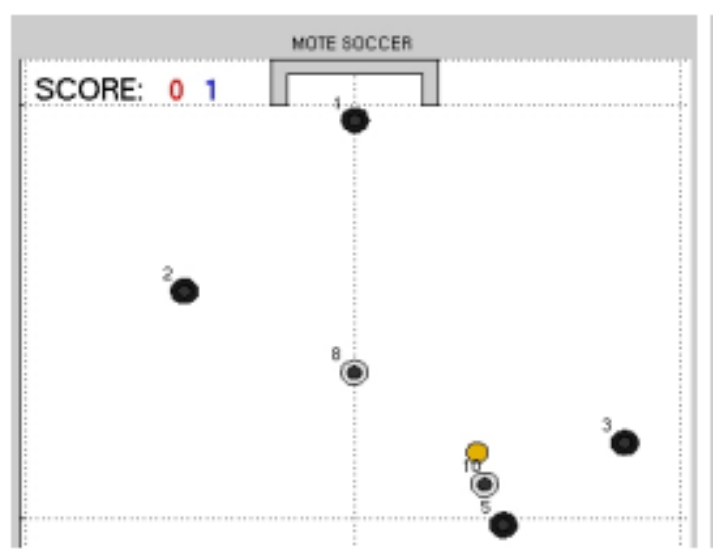

Gambar 10. Bola dikuasai oleh sebuah mote

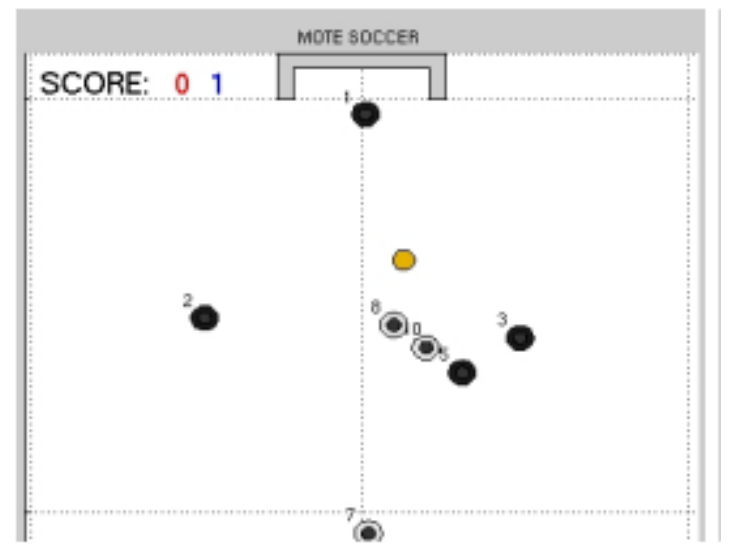

Gambar 11. Bola ditendang ke depan mendekati gawang

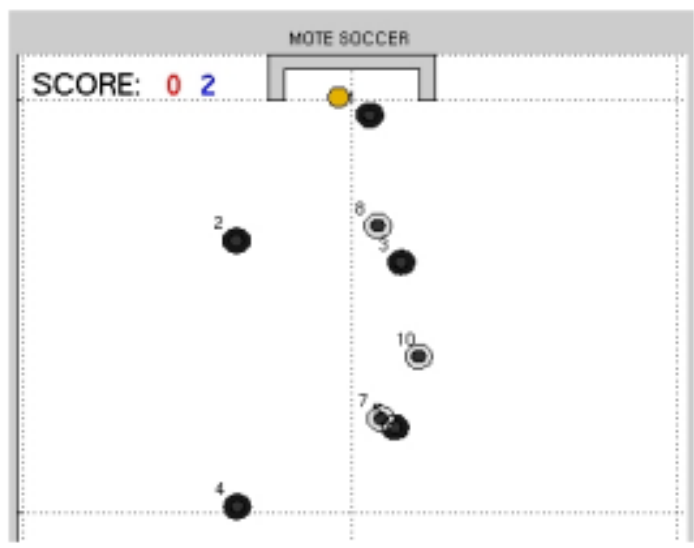

Gambar 12. Bola masuk ke dalam gawang

\section{KESIMPULAN}

Makalah ini telah menguraikan perspektif networked control system serta aplikasinya dalam robot sepakbola. Pertimbangan teknis dan praktis dalam membangun robot sepakbola mencakup pemilihan komponen sensor, prosesor, motor, dan kemampuan komunikasi antar robot. Sebuah perangkat simulasi yang disebut True Time Simulator juga telah diuraikan. Perangkat tersebut dapat digunakan dalam simulasi robot sepakbola dengan mengeksplorasi dinamika setiap robot dan kondisi komunikasi anta robotnya.

\section{DAFTAR PUSTAKA}

Aberkane, S., Ponsart, J.C. \& Sauter, D. (2008): Output-Feedback $\mathrm{H}_{2} / \mathrm{H}_{\infty}$ Control of A Class of Networked Fault Tolerant Control Systems, Asian Journal of Control Vol. 10, No. 1, January 2008, pp. $34-44$

Andersson, M., Henriksson, D., Cervin, A. \& Arzen, K. E. (2005): Simulation of Wireless Networked Control Systems, Proc. IEEE Conf. Decision \& Control 2005, pp. 476-481.

Argall, B., Gu, Y., Browning, B. \& Veloso, M. (2005): The First Segway Soccer Experience:Towards Peer-to-Peer Human-Robot Teams, Carnegie Mellon School of Computer Science, Technical Report CMU-CS-05-161, 2005.

Gao, H., Chen, T., \& Lam, J. (2008): A New Delay System Approach to Network-based Control, Automatica Vol. 44, No. 1, January 2008, pp. 39 -52 .

Heemels, W. P. M. H., et al. (2010): Networked Control Systems with Communication Constraints: Tradeoffs between Transmission Intervals, Delays and Performance, IEEE Trans. 
on Automatic Control, vol. 55, no. 8, pp. 1781 1796, August 2010.

Hespanha, J., Naghshtabrizi, P. \& Xu, Y. (2007): A Survey of Recent Results in Networked Control Systems, Proc. of The IEEE, vol. 95, no. 1, January 2007, pp.138-162.

Hirche, S., Chen, C-C., \& Buss, M. (2008): Performance Oriented Control Over Networks: Switching Controllers and Switched Time Delay, Asian Journal of Control Vol. 10, No. 1, January 2008, pp. $24-33$.

Ishii, H. (2008): $H_{\infty}$ control with limited communication and message losses, Systems \& Control Letters (57) 2008, pp. 322 - 331.

Jolly, K.G., Ravindran, K.P., Vijayakumar, R. \& Kumar, R.S. (2007): Intelligent decision making in multi-agent robotsoccer system through compounded artificial neural networks, Robotics and Autonomous Systems Journal, Vol. 55, No. 7, 31 July 2007, pp. 589-596.

Lam, J., Gao, H., \& Wang, C. (2007): Stability Analysis for Continuous Systems with Two Additive Time Varying Delay Components, Systems Control Letters, Vol. 56, No. 1, January 2007, pp. $16-24$.

Luo, R.C. (2000): Development of a multi-behavior based mobile robot for remote supervisory control through the Internet, Trans. on Mechatronics, Vol. 5, No. 4, pp. 376-385.

Ma, D., Dimirovski, G.M. \& Zhao, J. (2010): Hybrid state feedback controller design of networked switched control systems with packet dropout, Proc. of American Control Conference, June 30 July 2, 2010, pp.1368-1373.

Najmurrokhman, A., dkk. (2010), Output Feedback Controller for Dissipative Networked Control Systems via Markovian Jump System Approach", Proc. International Conf. on Intelligent Unmanned Systems, 3 - 4 Nov. 2010, Bali, Indonesia.

Nesic, D. \& Liberzon, D. (2009): A Unified Framework for Design and Analysis of Networked and Quantized Control Systems, IEEE Trans. on Automatic Control, vol. 54, no. 4, April 2009, pp. 732-747.
Rasool, F., Nguang, S. K. \& Krug, M. (2011): Robust $H \infty$ output feedback control of networked control systems with multiple quantizers, Proc. of IEEE Conf. on Industrial Electronics and Applications, 21-23 June 2011, pp. 1541-1546.

Sanfeliu, A., Hagita, N. \& Saffiotti, A. (2008): Network Robot Systems, Robotics and Autonomous Systems Journal, Vol. 56, No. 10, Oct. 2008, pp. 793-797.

Schiffer, S., Hoppe, N. \& Lakemeyer, G. (2012): Flexible Command Interpretation on an Interactive Domestic Service Robot, Proc. of the 4th International Conference on Agents and Artificial Intelligence (ICAART 2012), February 6 - 8, Vilamoura, Algarve, Portugal, 2012.

Shi, P., Yang, R. \& Gao, H. (2011): State Feedback Control for Networked Systems with Mixed Delays Subject to Quantization and Dropout Compensation, Proc. of Chinese Control and Decision Conference, 23-25 May 2011, pp. 295299.

Varsakelis, D. H. \& Levine, W. S. (2005): Handbook of Networked and Embedded Control Systems, Birkhauser, Boston.

Wang, Y. L., Liu, W. T., Zhu, X. L. \& Du, Z. (2011): A Survey of Networked Control Systems with Delay and Packet Dropout, Proc. of Chinese Control and Decision Conference, 23-25 May 2011, pp. 2342-2346.

Zhang, W., Branicky, M.S. \& Phillips, S.M. (2001): Stability of Networked Control Systems, IEEE Control Systems Magazine, Vol. 21, 2001, pp. 84 -99 .

Zhao, M. Y., Liu, H. P., Li, Z. J. \& Sun, D. H. (2011): Fault Tolerant Control for Networked Control Systems with Packet Loss and Time Delay, International Journal of Automation and Computing, vol. 8, no. 2, May 2011, pp.244-253. 